\title{
Equity Analysis in Buying Company Shares on the Philippine Stock Exchange
}

\author{
Prince T. Medina, ${ }^{1}$ Mary Caroline N. Castaño, ${ }^{2}$ Tomas S. Tiu ${ }^{3}$ \\ ${ }^{1,2,3}$ The Graduate School, University of Santo Tomas, España Boulevard, 1015 \\ Manila, Philippines
}

\begin{abstract}
Objective - Less than $1 \%$ of the population in the Philippines has invested in the stock market (PSE, 2016). The Philippine Stock Exchange (PSE) has been in operation since 1927 and is one of the oldest in the Asia Pacific. The primary objective of this research is to examine the investing techniques of online users using technical and fundamental analysis.

Methodology/Technique - A chi-square test is used to determine if there is a significant difference between the expected frequencies and the observed frequencies in one or more categories. The research probes the relationship of the demographic profiles of respondents and their investment behavior using the Friedman's test.

Findings - The descriptive statistics show the frequency counts of 418 observations and the corresponding chi-square test for the distribution-free data. The analysis of variance by ranks was used to reflect the Friedman test for the hierarchy of perception of the respondents per given variable. The chi-square test $\left(\chi^{2}(\mathrm{df}=4, \rho=0.001)=53.603\right)$ shows that actual observations on the relative valuation $(86,48,130,99$, and 55) is significantly different from a uniform fit of 84 observations at 4 degrees of freedom and 5\% level of significance.

Novelty - Hence, the study concluded that investors prefer a relative valuation equity selection strategy using fundamental analysis. Furthermore, the study concludes that the moving average $(36,11,80,95$ and 196) is preferred by investors using technical analysis.
\end{abstract}

Type of Paper: Empirical.

Keywords: Fundamental Analysis; Technical Analysis; Investment Behavior; Philippine Stock Exchange; Relative Valuation; Moving Average.

JEL Classification: G10, G14, G19.

\section{Introduction}

It is essential to understand the possible factors that may affect the current price of a stock. Investing in failing companies that have weak earnings or unethical practices may lead to the next Lehman Brothers.

\footnotetext{
${ }^{*}$ Paper Info: Received: September 10, 2018

Accepted: December 6, 2018

* Corresponding author: Prince T. Medina

E-mail: prince_medina@yahoo.com

Affiliation: Graduate School Student, University of Santo Tomas, Philippines
} 
Awareness of the equity selection of individuals will further an understanding into why pricing bubbles occur. Likewise, the existence of fundamental and technical analyses will be seen from the difference between investing methods. Based on the annual PSE report in 2017, online accounts increased by $28.5 \%$ from 302,516 in 2016 to 388,864 in 2017. Accounts have increased at a rate of 12.4\% from 773,187 in 2016 to 868,810 by the end of 2017 . Trading activities have propelled due to continued growth in online accounts. In $2017,53.7 \%$ of total market transactions, which is measured by the frequency of trades, stems from online accounts. An increase of $12.9 \%$ in value turnover led to a $9.3 \%$ share in the market's total value turnover in which it was the first year that online transactions had captivated more than $50 \%$ of the market's total trade. Local investors remain the majority holder of the overall stock market account with 759,952 or 98.2\%, while foreign investors hold 13,595 accounts which is equivalent to 1.8\% (PSE Academy, 2016). This paper will fill two essential gaps in knowledge by examining the investment behavior of an investor. First, there is limited literature on how investors purchase stock. Second, does the demographic profile of a respondent and their risk tolerance affect their investment behavior?

\section{Literature Review}

Behavioral finance began with the great work of Daniel Kahneman (1979), Richard Thaler (1985), Robert Shiller (2000) and Amos Tversky (1979). Several investment firms have already incorporated behavioral finance as a foundation of their investment strategies. Behavioral finance provides an analysis of the cause and effect behind irregular market patterns (Subrahmanyam, 2008). Further, Barber, Odean and Zhu (2009) mention that investors are likely to purchase the most active or "hot stocks."

\subsection{Fundamental Analysis}

Fundamental analysis is a process of assessing the intrinsic value of a company, by investigating interrelated economic and financial factors. According to Graham and Dodd (1934), stock market investors use financial statements to forecast future value. $\mathrm{Li}$ (2010) mentions that the disclosure of the quality of a firm is more significant when it faces stiff competition. This is consistent with the findings of Ali, Klasa and Yeung (2014) who state that frequency and management forecasts are more significant in more competitive industries. However, this is inconsistent with Safdar (2016) who states that the fundamental analysis is of less valuable in forecasting future returns if it faces greater competition. However, the ability of fundamentals to predict future stock yields is based on pricing errors by investors (Safdar, 2016). Buy and hold strategy holds stocks for decades as the prices are likely to grow (Chen, Kao, Lyuu \& Wong, 1999). Fundamental analysis began with Graham's book "The Intelligent Investor", which emphasizes purchasing equities based on value investing. According to Teixeira and Oliveira (2010), fundamental analysis is based on economic factors used to evaluate a company, while technical analysis is based on the historical data of stock price.

\subsection{Technical Analysis}

Technical Analysis is used to analyze historical prices, transaction volume and market activity by chart patterns and indicators to forecast the future price of a stock. Indicators and chart patterns are used to forecast future price movements. The distribution of supply and demand is the significant influence which modifies the stock's price and volume (Silva et al., 2013). Most technical analysts use the Moving Average (MA) system. However, that tool only interprets the period covered by the average. The MA gives equal weight to each day's price. An MA attempts to tone down the fluctuations in the stock market. The resulting number reflected is the mean average (Pring, 2014). The Relative Strength Index (RSI) measures the speed and magnitude of price movement. RSI indicates overbought and oversold conditions in the market. RSI is 
a bound oscillator which means that its numerical value oscillates or bounces within a range of between 0 and 100 (Cam, 2015).

\section{Research Methodology}

The research design used was Descriptive-Correlational. The objective of the study is to conduct an online survey of 400 respondents from the total of 89,800 members of the investing community through random sampling. Primary data was used. Investors on the Philippine Stock Exchange were assessed using a survey questionnaire with a five-level rating Likert Scale. The levels of measurement used were categorical and numerical levels. The study proponent gathered data from an online survey using Google Forms which were posted on investment blogging groups including Tsupiteros, Trader's Empire, and Investagrams Trading community. This group of investors should have online brokerage accounts to proceed with the survey. Minors and other incapacitated individuals were excluded from the study. Permission to post online on investment groups was requested from group administrators. In following the content of the form provided by the Ethics Review Committee, the subjects' participation was voluntary and they were able to depart from the study anytime they wanted to. The informed consent form included the objectives of the research and the benefits of the study. Two statistical tools were used to guarantee the reliability and validity of the interpretation of data. A chi-square test was employed in assessing the equity selection strategies. Friedman's Test was used in correlating education and the risk attitudes of an investor, civil status and percentage of cash allocated.

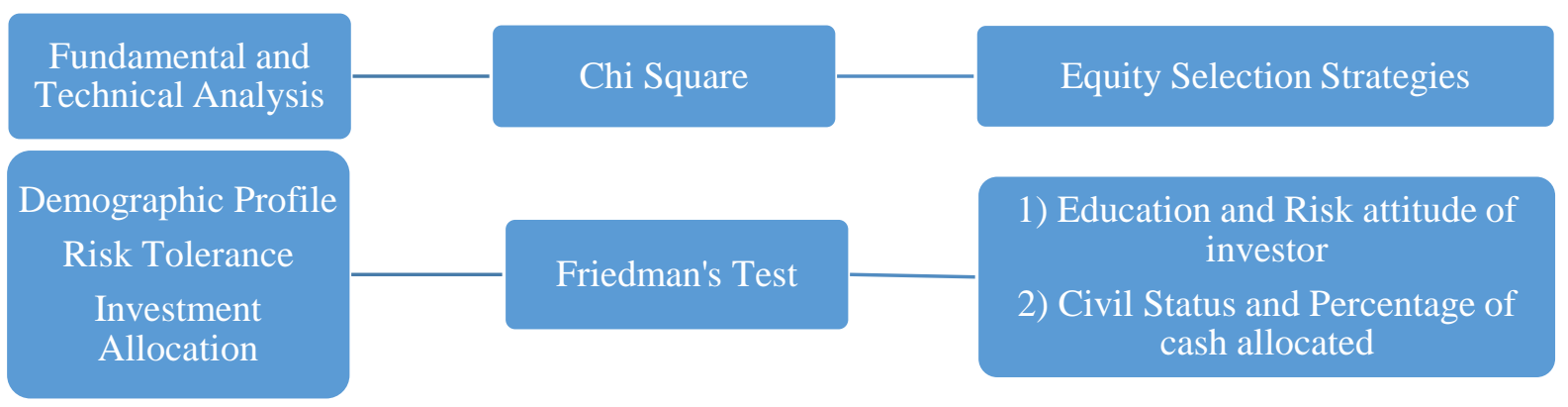

Figure 1. Conceptual Framework

\section{Results}

Table 1. Buying strategies of investors using fundamental analysis

\begin{tabular}{|c|c|c|c|c|c|c|c|c|}
\hline $\begin{array}{c}\text { Fundamental } \\
\text { Analysis }\end{array}$ & $\begin{array}{c}\mathbf{1 =} \\
\text { Neve } \\
\mathbf{r}\end{array}$ & $\begin{array}{c}\mathbf{2 =} \\
\text { Rarel } \\
\mathbf{y}\end{array}$ & $\begin{array}{c}\mathbf{3}=\text { Some } \\
\text { times }\end{array}$ & $\begin{array}{c}\text { 4= Most of } \\
\text { the Time }\end{array}$ & $\begin{array}{c}\mathbf{5}= \\
\text { Alway } \\
\mathbf{s}\end{array}$ & $\begin{array}{c}\text { Tot } \\
\text { al }\end{array}$ & $\begin{array}{c}\text { Wtd } \\
\text { mean }\end{array}$ & Chi-square \\
\hline $\begin{array}{c}\text { A) Relative } \\
\text { Valuation }\end{array}$ & 86 & 48 & 130 & 99 & 55 & 418 & $\begin{array}{c}2.97, \\
\text { sometimes }\end{array}$ & $\begin{array}{c}\chi 2(\mathrm{df}=4, \rho= \\
0.001)=53.603\end{array}$ \\
\hline $\begin{array}{c}\text { B) Dividend } \\
\text { Discount Model }\end{array}$ & 148 & 69 & 126 & 55 & 20 & 418 & $\begin{array}{c}2.35, \\
\text { rarely }\end{array}$ & $\begin{array}{c}\chi 2(\mathrm{df}=4, \rho= \\
0.001)=131.83\end{array}$ \\
\hline $\begin{array}{c}\text { C) Free Cash Flow } \\
\text { Model }\end{array}$ & 146 & 50 & 136 & 61 & 25 & 418 & $\begin{array}{c}2.45, \\
\text { rarely }\end{array}$ & $\begin{array}{c}\chi 2(\mathrm{df}=4, \rho= \\
0.001)=140.11\end{array}$ \\
\hline $\begin{array}{c}\text { D) Residual } \\
\text { Income Model }\end{array}$ & 156 & 48 & 134 & 56 & 24 & 418 & $\begin{array}{c}2.39, \\
\text { rarely }\end{array}$ & $\begin{array}{c}\chi 2(\mathrm{df}=4, \rho= \\
0.001)=159.85\end{array}$ \\
\hline
\end{tabular}




\begin{tabular}{|c|c|c|c|c|c|c|c|c|}
\hline $\begin{array}{c}\text { E) Net Asset } \\
\text { Value Model }\end{array}$ & 131 & 47 & 116 & 89 & 35 & 418 & $\begin{array}{c}2.64, \\
\text { sometimes }\end{array}$ & $\begin{array}{c}\chi 2(\mathrm{df}=4, \rho=001)=84.06 \\
0.00\end{array}$ \\
\hline $\begin{array}{c}\text { F) Value at Risk } \\
\text { Model }\end{array}$ & 136 & 37 & 128 & 76 & 41 & 418 & $\begin{array}{c}2.64, \\
\text { sometimes }\end{array}$ & $\begin{array}{c}\chi 2(\mathrm{df}=4, \rho= \\
0.001)=104.80\end{array}$ \\
\hline Average & 134 & 50 & 128 & 73 & 33 & 418 & $\begin{array}{c}2.57, \\
\text { sometimes }\end{array}$ & sometimes \\
\hline
\end{tabular}

Table 2. Buying strategies of investors using technical analysis

\begin{tabular}{|c|c|c|c|c|c|c|}
\hline Technical Analysis & $\begin{array}{c}1= \\
\text { Never }\end{array}$ & $\begin{array}{c}2= \\
\text { Rarely }\end{array}$ & $\begin{array}{c}3= \\
\text { Sometimes }\end{array}$ & $\begin{array}{c}4=\text { Most of the } \\
\text { Time }\end{array}$ & $\begin{array}{c}5= \\
\text { Always }\end{array}$ & $\begin{array}{c}\text { Tota } \\
1\end{array}$ \\
\hline Moving Average & 36 & 11 & 80 & 95 & 196 & 418 \\
\hline Relative Strength Index & 51 & 26 & 80 & 83 & 178 & 418 \\
\hline Fibonacci & 97 & 33 & 121 & 79 & 88 & 418 \\
\hline Bollinger Band & 128 & 47 & 102 & 65 & 76 & 418 \\
\hline Stochastic Oscillator & 140 & 53 & 90 & 74 & 61 & 418 \\
\hline $\begin{array}{c}\text { Volume Weighted Average } \\
\text { Price }\end{array}$ & 161 & 51 & 94 & 59 & 53 & 418 \\
\hline Average True Range & 161 & 43 & 108 & 70 & 36 & 418 \\
\hline Elliot Wave Theory & 170 & 46 & 115 & 59 & 28 & 418 \\
\hline Commodity Channel Index & 176 & 47 & 106 & 59 & 30 & 418 \\
\hline Williams\%R & 208 & 51 & 99 & 42 & 18 & 418 \\
\hline Average & 132.8 & 40.8 & 99.5 & 68.5 & 76.4 & 418 \\
\hline
\end{tabular}

Table 3. Education and risk attitude of an investor

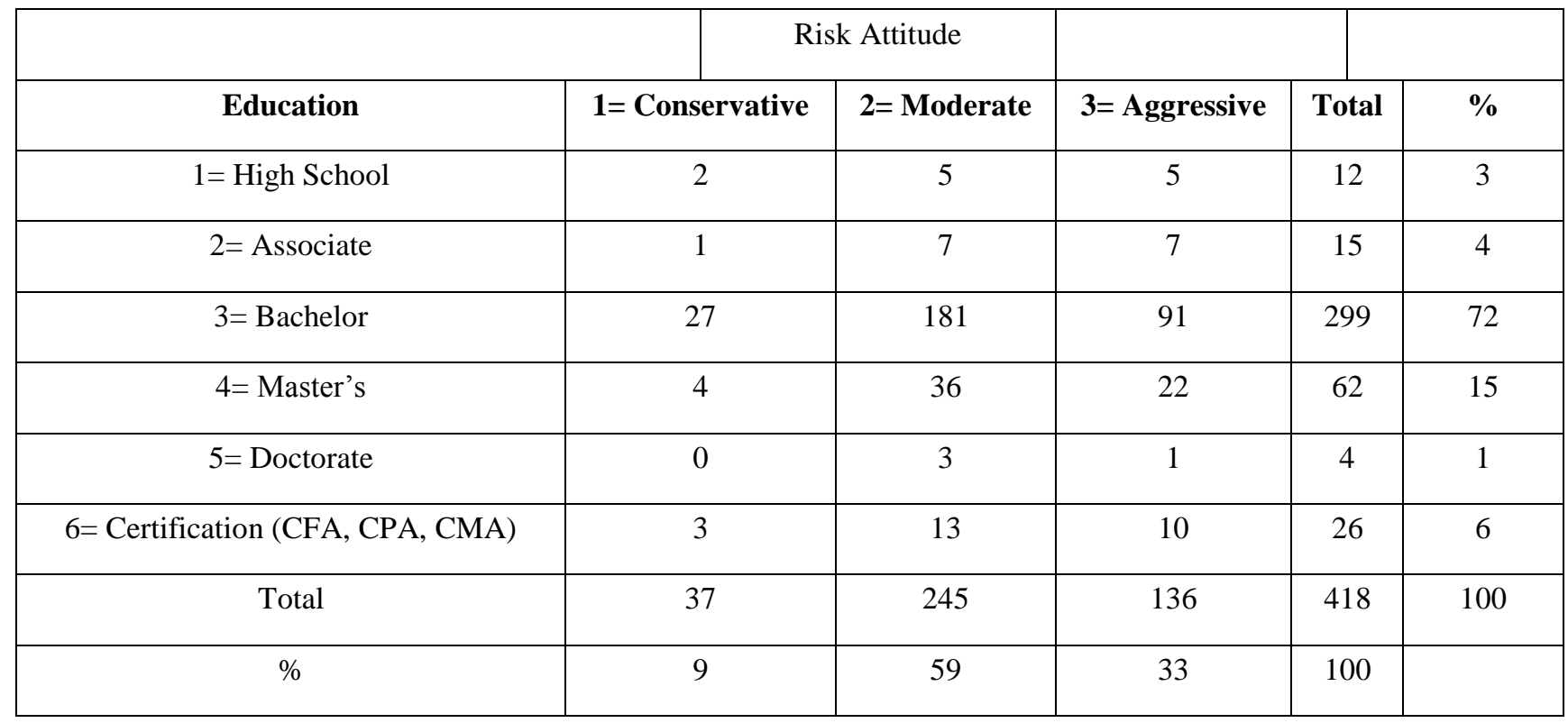


Table 4. Civil Status and cash allocated of an investor

\begin{tabular}{|c|c|c|c|c|c|c|}
\hline \multirow{2}{*}{ Percentage of cash allocated in the stock market } & \multicolumn{4}{|c|}{ Civil Status } & \multirow[b]{2}{*}{ Total } & \multirow[b]{2}{*}{$\%$} \\
\hline & $1=$ Single & $2=$ Married & $3=$ Separated & $4=$ Widowed & & \\
\hline $1=0-25 \%$ & 74 & 79 & 3 & 0 & 156 & 37 \\
\hline $2=26-50 \%$ & 92 & 64 & 3 & 1 & 160 & 38 \\
\hline $3=51-75 \%$ & 37 & 20 & 2 & 0 & 59 & 14 \\
\hline $4=76-100 \%$ & 25 & 17 & 1 & 0 & 43 & 10 \\
\hline Total & 228 & 180 & 9 & 1 & 418 & 100 \\
\hline$\%$ & 55 & 43 & 2 & 0 & 100 & \\
\hline
\end{tabular}

\section{Conclusion}

Evaluation of the equity selection strategies shows that the dividend discount model, residual income valuation model, and free cash flow model are rarely used as a strategy, while relative valuation, net asset value model and value at risk model are moderately used. In order, Friedman's test for analysis of variance by rank $\left(\chi^{2}(\mathrm{df}=5, \rho=0.001)=191.80\right)$ shows that relative valuation, net asset value model and value at risk model were ranked highest. The least used equity selection strategies include dividend discount model, residual income valuation model, and free cash flow model. The study determines that educational level has a significant effect on the risk attitude of an investor. The higher their level of education, the more likely they are to become aggressive investors rather than conservative. The Friedman test shows that there is a significant difference in the civil status of respondents to cash allocated at a 5\% level of significance. The results show that approximately $37 \%$ and $38 \%$ of single and married investors allocate $0-25 \%-26-50 \%$ of their cash in the stock market.

The chi-square test $(\chi 2(\mathrm{df}=4, \rho=0.001)=53.603)$ shows that actual observations on relative valuation $(86,48,130,99$, and 55) were significantly different from a uniform fit of 84 observations at 4 degrees of freedom and a 5\% level of significance. Hence, the study concludes that investors prefer relative valuation in using fundamental analysis. Furthermore, the study concludes that the moving average (36, 11, 80, 95 and 196) is preferred by investors using technical analysis. The equity selection purchasing strategy of a person is differentiated by multiple reasons such as educational attainment, cash availability, civil status, risk tolerance, portfolio allocation, investment behavior and knowledge in fundamental and technical analysis. Investors in PSE are unfamiliar with Fundamental Analysis and rely heavily on Moving Average and Relative Strength Index on Technical Analysis. Knowing if the company is still profitable is as essential as knowing the price movements in the stock market because business valuation is correlated with stock valuation. Investment literacy, risk tolerance, and cash allocation are key requirements in becoming a successful investor in the stock market.

\subsection{Recommendations}

To increase the population of investors in PSE, an in-depth financial literacy on equities is required, particularly on schools and colleges. A security analysis course is offered by Columbia University, the University of London and the NY Institute of Finance. The course focuses on Value Investing which Warren 
Buffett learned from his mentor Benjamin Graham. Equities should be discussed intensively together with bonds as money invested for an extended period has the highest probability of obtaining financial freedom as this capital is used for the expansion of a business. This can be passive income generation for investors which will create economic growth for a country. Investment Management should be tackled in senior high school for primary awareness. This research contributes to the academic , PSE and to the investment community.

\section{References}

Abdel, O. and Khasawneh, H. (2017) Noise Trading In Small Markets: Evidence from Amman Stock Exchange (ASE) Research in International Business and Finance, 42, 422-428.

Bamiatzi, V., Bozos, K. and Lambertides, N. (2016) Mapping the Trading Behavior of the Middle Class in Emerging Markets: Evidence From the Istanbul Stock Exchange. International Business Review, 25, 679-690.

Cahill, D., Wee, M. and Yang, J. W. (2017) Media Sentiment and Trading Strategies of Different Types of Traders Pacific-Basin Finance Journal, 44, 160-172.

Call, B., A., Clement, M. and Sharp, N. (2016) The Activities of Buy-side Analysts and the Determinants of Their Stock Recommendations. Journal of Accounting and Economics, 62, 139-156.

Chan, K., Li, F., Linc, J.C. and Lind, T.C. (2017) What Do Stock Price Levels Tell Us About the Firms? Journal of Corporate Finance, 46, 34-50.

Cici, G. and Rosenfeld C. (2016) A Study of Analyst-run Mutual Funds: The Abilities and Roles of Buy-side Analysts. Journal of Empirical Finance, 36, 8-29.

Crafts, N. and Fearon, P. (2013) The Great Depression of the 1930s: Lessons For Today New York: Oxford University Press. 2013.

Dichtl, H., Drobetz, W. and Kryzanowski, L. (2016) Timing the Stock Market: Does It Really Make No Sense? Journal of Behavioral and Experimental Finance, 10, 88-104.

Duxbury, D. and Yao, S. (2017) Are Investors Consistent in Their Trading Strategies? An Examination of Individual Investor-level Data. International Review of Financial Analysis, 52, 77-87.

Eraker, B. and Ready, M. (2015) Do Investors Overpay for Stocks With Lottery-like Payoffs? An Examination of the Returns of OTC Stocks. Journal of Financial Economics, 115, 486-504.

Gerritsen, D. F. (2016) Are Chartist Artists? The Determinants and Profitability of Recommendations Based on Technical Analysis. International Review of Financial Analysis, 47, 179-196.

Hana, X. and Li, Y. (2017) Can Investor Sentiment be a Momentum Time-series Predictor? Evidence from China. Journal of Empirical Finance, 42, 212-239.

Harper, J.T., Iyer, S. R. and Nejadmalayeri, A. (2017) Diversification Discount and Investor Sentiment. North American Journal of Economics and Finance, 42, 218-236.

Kaplanski, G. and Levy. H., (2017) Analysts and Sentiment: A Causality Study. The Quarterly Review of Economics and Finance, 63, 315-327.

Khan, H. H., Naz, I., Qureshi, F and Ghafoor, A. (2017) Heuristics and Stock Buying Decision: Evidence from Malaysian and Pakistani Stock Markets. Borsa Istanbul Review, 17-2, 97-110.

Khan, M. T. I., Tan, S. H., Chong, L. L., \& Ong, H. B. (2017). Investment characteristics, stock characteristics and portfolio diversification of finance professionals. Borsa Istanbul Review, 17(3), 164-177.

Lee, B., Rosenthal, L., Veld, C., \& Veld-Merkoulova, Y. (2015). Stock market expectations and risk aversion of individual investors. International Review of Financial Analysis, 40, 122-131.

Liang, W. L. (2016). Sensitivity to investor sentiment and stock performance of open market share repurchases. Journal of Banking \& Finance, 71, 75-94.

Litimi, H., BenSaïda, A., \& Bouraoui, O. (2016). Herding and excessive risk in the American stock market: A sectoral analysis. Research in International Business and Finance, 38, 6-21.

Maginn J. L., Tuttle, D.L., McLeavey, D.W., \& Pinto J.E., (2007) Managing Investment Portfolios Wiley; 3 edition (March 9, 2007)

Minton, B. A., \& Schrand, C. (2016). Institutional investments in pure play stocks and implications for hedging decisions. Journal of Corporate Finance, 37, 132-151.

Miwa, K. (2016). Investor sentiment, stock mispricing, and long-term growth expectations. Research in International Business and Finance, 36, 414-423. 
Moussa, F., BenOuda, O., \& Delhoumi, E. (2017). The use of open source internet to analysis and predict stock market trading volume. Research in International Business and Finance, 41, 399-411.

Nartea, G. V., Kong, D., \& Wu, J. (2017). Do extreme returns matter in emerging markets? Evidence from the Chinese stock market. Journal of Banking \& Finance, 76, 189-197.

Piccoli, P., Chaudhury, M., Souza, A., \& da Silva, W. V. (2017). Stock overreaction to extreme market events. The North American Journal of Economics and Finance, 41, 97-111.

Reilly, F.K., \& Brown, K.C. (2006) Investment Analysis and Portfolio Management 8th Edition Southwestern College; 8th edition (2005)

Renault, T. (2017). Intraday online investor sentiment and return patterns in the US stock market. Journal of Banking \& Finance, 84, 25-40.

Safdar, I. (2016). Industry competition and fundamental analysis. Journal of Accounting Literature, 37, 36-54.

Siganos, A., Vagenas-Nanos, E., \& Verwijmeren, P. (2017) Divergence of sentiment and stock market trading Journal of Banking and Finance 78 130-141

Usul, N., Özdemir, Ö., \& Kiessling, T. (2017). Affect-based stock investment decision: The role of affective selfaffinity. Journal of behavioral and experimental economics, 68, 97-109.

Wafi, A. S., Hassan, H., \& Mabrouk, A. (2015). Fundamental Analysis Models in Financial Markets-Review Study. Procedia economics and finance, 30, 939-947.

Yang, C., \& Zhou, L. (2016). Individual stock crowded trades, individual stock investor sentiment and excess returns. The North American Journal of Economics and Finance, 38, 39-53. 